\title{
Making the connection between healthy waterways and healthy catchments: South East Queensland, Australia
}

\author{
S. E. Bunn*, E. G. Abal**, P. F. Greenfield*** and D. M. Tarte** \\ * Australian Rivers Institute, Griffith University, Nathan, Queensland, Australia, 4111. \\ (E-mail: S.Bunn@griffith.edu.au) \\ ** SEQ Healthy Waterways Partnership, Corner George and Adelaide Streets, Brisbane, Queensland, \\ Australia 4072. (E-mail: e.abal@uq.edu.au; Di.Tarte@healthywaterways.org) \\ *** Office of the Senior Deputy Vice Chancellor, The University of Queensland, St Lucia, Queensland, \\ Australia 4072. (E-mail: p.greenfield@uq.edu.au)
}

\begin{abstract}
The waterways of South East Queensland, Australia, represent unique and complex ecosystems that have a high conservation value and support major recreational and commercial fisheries. The agricultural districts of the region also contribute significantly to the regional economy and, together with the growing urban areas, are heavily reliant on good quality water supplies. However, the human footprint of these activities has led to significant changes in catchment hydrology and sediment delivery, declining water quality and loss of aquatic biodiversity. Predicted population increases in the region are likely to further impact on the ecological and economic health of its waterways and catchments, and there are growing community expectations to reverse the decline in water quality and ecosystem health. In response to these concerns, government, industry and community stakeholders have worked in close cooperation to develop a whole-of-government, whole-of-community approach to understanding and managing the region's waterways. This paper provides an overview of the experience gained through development of the SEQ Healthy Waterways Partnership and highlights some of the key factors we believe have contributed to its success.

Keywords Adaptive management, ecosystem health, estuaries, monitoring, rivers, water quality
\end{abstract}

\section{INTRODUCTION}

South East Queensland (SEQ), Australia provides an excellent case study of the challenges for ecological sustainable management of rivers and coastal ecosystems in the face of population and climate change (Dennison and Abal, 1999; Abal et al., 2005a). The region's waterways represent unique and complex ecosystems that have a high conservation value and support major recreational and commercial fisheries. The agricultural districts of the region also contribute significantly to the regional economy and, together with the growing urban areas, are heavily reliant on the availability of good quality water supplies. However, the human footprint of these activities has led to significant changes in catchment hydrology and sediment delivery, declining water quality and loss of aquatic biodiversity. Nutrients (particularly nitrogen) and fine sediments have been identified as causes of significant environmental problems. Predicted population increases in the region are likely to further impact on the ecological and economic health of its waterways and catchments, and there are growing community expectations about reversing the trend of decline in water quality and ecosystem health.

In response to these concerns, government, industry and community stakeholders have worked in close cooperation to develop a whole-of-government, whole-of-community approach to understanding and managing the region's waterways. The key elements of this SEQ Healthy Waterways Partnership include: the implementation by a range of partners of management actions ranging from upgrades of sewage treatment plants, to improved planning regimes and rehabilitation of riparian vegetation; a multi-disciplinary science, research and monitoring program that underpins the management action program and monitors its effectiveness; and the Healthy Waterways 
promotional and educational program that seeks to build on similar activities of partners and ensure that there is community awareness and support for action. This paper provides an overview of the experience gained through development of the Partnership and highlights some of the key factors we believe have contributed to its current success.

\section{THE STUDY REGION}

The South East Queensland (SEQ) region extends from the city of Noosa to the New South Wales border at the Gold Coast, and west to the Great Dividing Range (Figure 1). It covers 15 major catchments with a combined catchment area of $22,672 \mathrm{~km}^{2}$, and includes 18 local governments. More than 2.5 million people currently live within 50 kilometres of the coast and enjoy a high standard of living within a diverse economy, in what is the fastest growing region in Australia (Abal et al., 2005b).

The SEQ region's waterways have significant environmental, economic and social values. Moreton Bay is a marine park and is listed as a wetland of international significance under the Ramsar Convention for the protection of wetland habitats and migratory birds. The Bay and estuaries support major commercial and recreational fisheries and are extensively used for recreation. The catchments are the region's major water supply, for primarily urban but also rural use (Abal et al., 2005b).

However, human activity since European settlement has left a significant ecological footprint. Only about one quarter of the original vegetation in the region remains intact, though much less occurs along stream and river corridors in some catchments. The catchment hydrology has been substantially altered, not just through the construction of dams and weirs but also because of changes in land-use and vegetation that have resulted in altered run-off responses to rainfall events, generating 'flashier' stream flows. Nutrients (particularly nitrogen), fine sediments and, to a lesser extent, toxicants (pesticides and heavy metals) have been identified as causes of significant environmental problems. The high catchment to bay ratio for Moreton Bay (14:1) is a complicating factor and results in residence times that range from days in the eastern Bay to several months in the western embayments (Fig 1.; Abal et al., 2005b). This can compound water quality problems in the latter regions.

Concerns about the future security of water supply (both in terms of quantity and quality) and the viability of industries that are dependent on healthy waterways (e.g. tourism, fishing), in the face of a rapidly growing population and changing climate, have been major drivers for change in the way that waterways and catchments are managed in the region. This has been accompanied by increasing community expectations for improved water quality and ecosystem health and a growing recognition that it is cheaper to protect environmental assets of high value than to try and restore them. Initial work has identified a range of social and economic impacts resulting from factors such as increased health risks, loss of income, reduced recreation and tourism opportunities, and increased water treatment costs (Rolfe et al. 2005). 


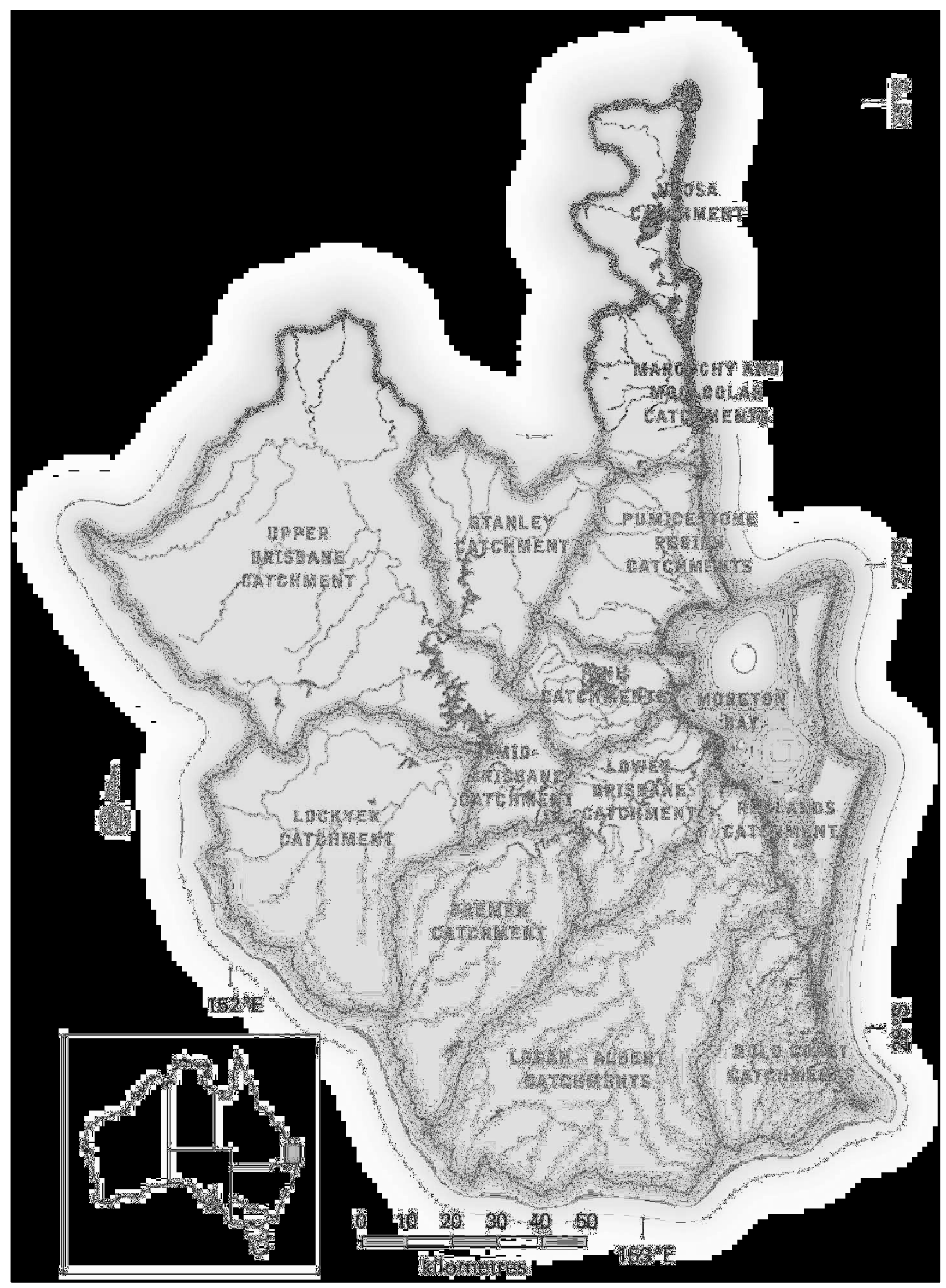

Figure 1 The South East Queensland region, showing the different catchments and Moreton Bay (from Abal et al., 2005). 


\section{SEQ HEALTHY WATERWAYS PARTNERSHIP}

Although public concern about declining water quality in Moreton Bay and the Brisbane River was noted in the mid-1970s, it was only in the 1990s that a coordinated approach to addressing this decline began. The Brisbane River Management Group started in 1993, and was extended to include all South East Queensland (SEQ) waterways in 2001 with the development of the SEQ Regional Water Quality Management Strategy (SEQRWQMS). This resulted in the formation of the Moreton Bay Waterways and Catchments Partnership in 2002 - now known as the SEQ Healthy Waterways Partnership.

The Strategy was a joint Federal, State and local government initiative and was developed directly by a broad range of stakeholders. This allowed an effective, "whole of community" approach to the development and agreement of the management actions contained in the Strategy. The Strategy was overseen by a Management Committee of elected officials from the sponsoring councils, senior officers from the sponsoring State Government departments and elected industry and community representatives. It was also supported by a Scientific Expert Panel, a Technical Advisory Group of officers from State Government departments and local governments, and an Industry and Community Advisory Group of non-government representatives from industry, fishing, conservation, catchment management, Landcare and indigenous groups. Consultation with the wider community was also undertaken.

\section{Healthy waterways vision}

An important aspect of the Strategy was the development and agreement by all stakeholders, at an early stage in the process, of a single, clear vision for the future health of the region's waterways. This was that:

\section{"By 2020, our waterways and catchments will be healthy ecosystems supporting the livelihoods and lifestyles of people in South-east Queensland, and will be managed through collaboration between community, government and industry."}

The initial approach taken was to identify the values for the region's waterways that reflected the above vision. This involved numerous workshops with stakeholders from across the region. Once an agreed set of values (assets) was identified, measurable water quality or ecosystem health objectives were then set to protect these values. This was underpinned by a robust science program. Finally, management actions were identified to achieve these objectives, working directly with policy makers.

\section{STAGED APPROACH TO RESEARCH AND MONITORING}

The SEQ Healthy Waterways Partnership has adopted a staged approach in the development of the Strategy and its associated research program. Stage 1 (1993 to 1995) reviewed available information and delivered a framework for the development of the Strategy. Stage 2 (1996 to 1998) focused on urban areas in the lower catchment, marine and estuarine areas of the Moreton Region and was developed by six local councils, the Environmental Protection Agency and other state agencies, industry and community.

A key outcome of the early work in Stage 2 was the identification of major point source impacts from sewage treatment plants in the lower Brisbane River and western Moreton Bay, and the recognition that nitrogen was a pollutant of particular concern and linked to algal blooms (Dennison and Abal, 1999; Udy and Dennison, 2005). A major plume of organic-rich sediments was also identified at the mouth of the Brisbane River and continual resuspension of fine sediments and associated increased turbidity had resulted in major declines in seagrass in the western embayments. 
In turn, this had led to declines in populations of dugongs, turtles and other biota dependent on shallow seagrass habitats.

\section{Catchment diffuse loads}

Stage 3 (1999 to 2001) of the Strategy focused on the freshwater catchment areas of the Moreton region and incorporated the north (Noosa, Maroochy and Mooloolah) and south (Logan, Albert and Gold Coast) regions.

A major focus of research in Stage 3 was on the catchment sources of sediments that ultimately find their way into Moreton Bay and estuaries. More specifically, where did the sediment come from and what were the processes that generate it? Initial catchment modelling suggested that $60 \%$ of the sediment in Moreton Bay originated from $<30 \%$ of the region (south-western catchments - see Fig. 1). Tracer studies of sediment cores taken from the Bay and rivers confirmed that most sediment came from specific soil types that predominate in this region (Caitcheon and Howes, 2005).

Having identified the major areas contributing sediments, it was also important to identify the dominant processes that generate them. Hillslope erosion is likely to be a major process in steeper catchments and in areas with intensively cropped floodplains. In areas where this dominates, the management solutions include promoting better ground cover, maintaining soil structure and attempting to trap eroding sediments in buffer strips before they enter waterways. Channel erosion (including bank erosion and gullying), on the other hand, is promoted by high stream energy and is exacerbated by the loss of protective riparian vegetation and floodplain degradation. In areas where this process dominates, the management interventions include protection or rehabilitation of riparian vegetation, and the control of stock access (Marsh et al., 2005).

Catchment modelling predicted that channel erosion dominates throughout much of the region and this finding was supported by tracer studies (Caitcheon and Howes, 2005). The other major source of sediment was from erosion of cultivated surface soils. This result was not surprising given that about $50 \%$ of the $48,000 \mathrm{~km}$ of streams in South East Queensland has poor riparian condition. Poor riparian condition is also a major cause of poor water quality and aquatic ecosystem health in streams in the region (Bunn et al., 1999; Smith et al., 2005).

For much of the time, streams in the region lack surface flows and are dry channels. In intensive rain events, channel erosion results because of increased run-off and poor riparian condition. Proposed management interventions include protecting and, where necessary, rehabilitating riparian vegetation and increasing channel roughness to slow run-off, stabilise gullies and small stream banks, and filter sediments and associated nutrients. In the more perennial flowing streams, riparian restoration is also the key to improving stream health. Many water quality and ecosystem health indicators have been shown to be influenced by riparian condition. In small streams (up to about 10 $\mathrm{m}$ active channel width), achieving a $70 \%$ canopy cover effectively shades the stream, moderating temperature extremes and controlling nuisance aquatic plants (Rutherford et al., 2004; Davies et al. 2007). Riparian restoration along larger waterways may provide important wildlife habitat and have a high amenity value, but research shows that we cannot address diffuse pollution from sediment and nutrients unless it is tackled in the source streams.

\section{Development of decision support software}

An important activity in Stage 3 of the Strategy was the development of an Environmental Management Support System (EMSS). This decision support tool was specifically developed to meet the requirements of the Partnership and integrated a run-off pollutant export model, a routing model and a storage model (Vertessey and McAlister, 2005). The output of this 3-linked catchment 
model was then fed into a Receiving Water Quality Model developed for the tidal waterways and Moreton Bay. These modelling tools, supported by local scientific information, provided the means to explore how catchment-derived (point and diffuse) loads of sediment and nutrients influenced ambient water quality, and to assess whether water quality objectives can be met. This provided an important direct or causative link between catchment loads and associated waterway ecosystem health.

Decision support tools such as the Environmental Management Support System (EMSS) and the Receiving Water Quality Models, are useful not only in evaluating the relative efficacy of various management actions aimed at the improvement of water quality, but can also assist stakeholders in determining sustainable loads and setting environmental targets for waterways. Various scenarios can be tested, based on past, current and future land use condition and applying various management 'interventions' (e.g. from 'do nothing' to applying water sensitive urban design, sewage treatment upgrades, or major riparian restoration).

\section{Monitoring the effectiveness of environmental protection measures}

A comprehensive estuarine and marine Ecosystem Health Monitoring Programme (EHMP) was developed in Stage 2 of the Strategy and implemented in Stage 3 (Smith and Grice, 2005). This program involves routine (monthly) sampling of water quality parameters at over 260 sites across the region. Other measures of ecosystem health (e.g. seagrass mapping) are also undertaken.

The Freshwater EHMP was developed in Stage 3 of the Strategy and implemented in 2002. This involves the measurement of 16 parameters, including measures of fish and invertebrate biodiversity, ecosystem processes and water quality, at over 120 stream sites across the region, twice per year (Kennard et al., 2005; Smith and Grice, 2005; Fellows et al., 2006; Udy et al., 2006).

Water quality or ecosystem health objectives have been set to underpin values identified by stakeholders (consistent with the Healthy Waterways vision). The indicators in the EHMP have been carefully selected and tested as either specific measures of these assets or parameters that are known to have a direct influence on them.

\section{ADAPTIVE MANAGEMENT FRAMEWORK}

Consistent with the philosophy of adaptive management (Figure 2), the Healthy Waterways Partnership is committed to (i) ongoing knowledge acquisition, (ii) the critical importance of monitoring; (iii) continuous improvement in the identification and implementation of management; and (iv) effective communication of knowledge for policy/planning. The approach recognises that management intervention can seldom be postponed until all of the information required to fully understand the situation is available (Abal et al., 2006).

Some key ingredients for success include:

(i) The development and public presentation of 'Report cards' on the health of waterways in the region. These are based on the robust EHMP data and presented to senior policy makers each year in a public (televised) ceremony.

(ii) The continual refinement and testing of conceptual models. These are not only used to improve our scientific understanding and identify key knowledge gaps but also to communicate important processes to stakeholders.

(iii) A strong link between science and policy makers. The Partnership model has facilitated an open dialogue between the Scientific Expert Panel and key local and State Government policy makers and managers. 
(iv) Targeted management actions, including STP upgrades, riparian restoration, stormwater quality improvement devices.

(v) Monitoring of effectiveness of management actions. Developing targeted monitoring programs to assess effectiveness of management interventions (e.g. monitoring sewage treatment plant upgrades using $\delta^{15} \mathrm{~N}$ tracers - e.g. Costanzo et al., 2005).

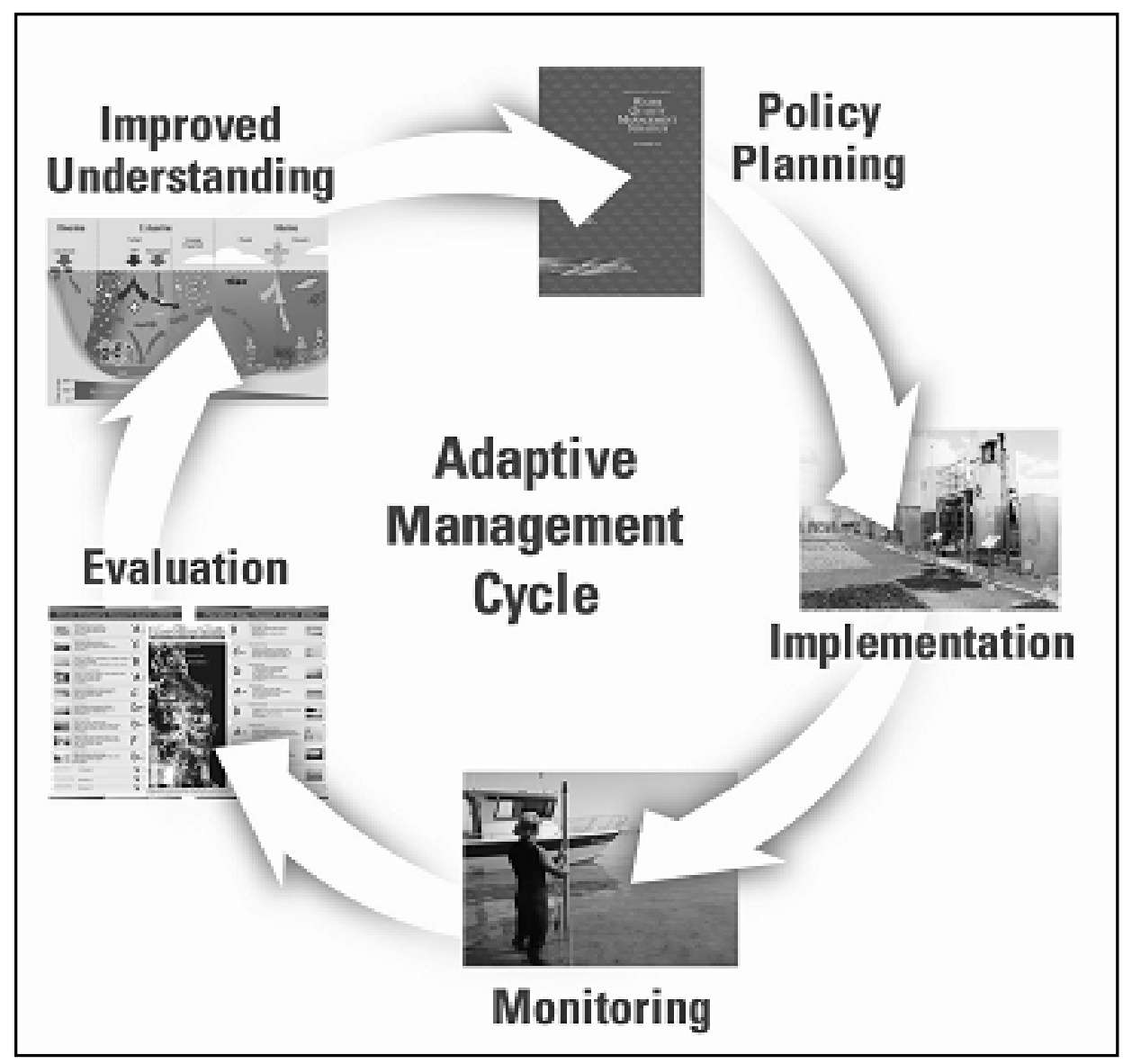

Figure 2 The adaptive management framework used in the Healthy Waterways Partnership (from Abal et al., 2005).

\section{CONCLUSIONS}

There are several key lessons from the SEQ Healthy Waterways Program that are likely to be transferable to other regional catchment management programs aimed at improving water quality and aquatic ecosystem health. These include, the importance of a shared common vision, the involvement of committed individuals (scientists, politicians, managers, community), a cooperative approach, the need for defensible science, and effective communication. These factors have been important in the development and success of the Healthy Waterways Partnership in South East Queensland. Furthermore, without this approach, it would not have been possible to stimulate the growing recognition in the region of the important connections between healthy waterways and their catchments. 


\section{REFERENCES}

Abal E. G., Bunn S. E. and Dennison W. C. (eds) (2005a). Healthy Waterways, Healthy Catchments: Making the connection in south east Queensland, Moreton Bay and Catchments Partnership, Brisbane Queensland, 222p.

Abal E. G., Dennison W. C. and Bunn S. E. (2005b). Setting. In: E. G. Abal, S. E. Bunn and W. C. Dennison (eds), Healthy Waterways, Healthy Catchments: Making the connection in south east Queensland, Moreton Bay and Catchments Partnership, Brisbane Queensland, pp. 13-34.

Abal E. G., Greenfield P. F., Bunn S. E. and Tarte D. M. (2006). Healthy Waterways: Healthy Catchments - An Integrated Research/Management Program to Understand and Reduce Impacts of Sediments and Nutrients on Waterways in Queensland, Australia. Frontiers of WWW Research and Development - APWeb 2006: 8th Asia-Pacific Web Conference, Harbin, China, January 16-18, 2006. Proceedings. pp. 1126-1135.

Bun, S. E., Davies, P. M., and Mosisch T. D. (1999). Ecosystem measures of river health and their response to riparian and catchment degradation. Freshwater Biology, 41, 333-345.

Caitcheon G. and Howes T. (2005). Sediments. In: E. G. Abal, S. E. Bunn and W. C. Dennison (eds), Healthy Waterways, Healthy Catchments: Making the connection in south east Queensland, Moreton Bay and Catchments Partnership, Brisbane Queensland, pp 69-92.

Costanzo S. D., Udy J., Longstaff B. and Jones A. (2005). Using nitrogen stable isotope ratios $\left(\delta^{15} \mathrm{~N}\right)$ of macroalgae to determine the effectiveness of sewage upgrades: changes in the extent of sewage plumes over four years in Moreton Bay, Australia, Marine Pollution Bulletin, 51, 212-217.

Davies P. M., Bunn S., Mosisch T., Cook B. and Walshe T. (2007). Temperature and light. In: S. Lovett, \& P. Price, (eds.) Principles for riparian lands management, Land and Water Australia, Canberra, pp 33-46.

Dennison W. C. and Abal E. G. (1999). Moreton Bay Study: a scientific basis for the healthy waterways campaign. South East Queensland Regional Water Quality Management Strategy. 245pp.

Fellows C. S., Clapcott J. E., Udy J. W., Bunn S. E., Harch B. D. and Davies P. M. (2006). Benthic metabolism as an indicator of stream ecosystem health. Hydrobiologia, 572, 71-87.

Kennard M. J. Arthington A. H. Pusey B. J. Harch B. D. (2005). Are alien fish a reliable indicator of river health? Freshwater Biology 50 (1), 174-193.

Marsh N. A., Rutherfurd I. and Bunn S. (2005). Suspended sediment yield following riparian revegetation in a small southeast Queensland stream. In I. Rutherfurd, I. Wiszniewski, M. AskeyDoran and Glazik R. (eds). Proceedings of the Fourth Australian Stream Management Conference, Launceston, October 2004, pp 410-14.

Marsh N. A., Bunn S. and Rutherford J. C. (2005). Restoring water temperature regimes of small streams with riparian revegetation. . In I. Rutherfurd, I. Wiszniewski, , M. Askey-Doran, and R Glazik,. (eds). Proceedings of the Fourth Australian Stream Management Conference, Launceston, October 2004, pp 403-9

Rolfe J., Donaghy P., Alam K., O’Dea G. and Miles R. (2005). Considering the economic and social impacts of protecting environmental values in specific Moreton Bay/SEQ, Mary River Basin/Great Sandy Strait Region and Douglas Shire Waters. Institute for Sustainable Regional Development, Central Queensland University, Rockhampton.

Rutherford J. C., Marsh N. A., Davies P. M. and Bunn S. E. (2004). Effects of patchy shade on stream water temperature: how quickly do small streams heat and cool? Marine and Freshwater Research 55, 737-748.

Smith M., Carruthers T. and Bunn S. E. (2005). Aquatic Habitats. In: E. G. Abal, S. E Bunn and W. C. Dennison, Healthy Waterways, Healthy Catchments: Making the connection in south east Queensland, Moreton Bay and Catchments Partnership, Brisbane Queensland, pp 35-68.

Smith M. and Grice A. (2005). Ecosystem Health Monitoring Program. In: E. G. Abal, S. E. Bunn and W. C. Dennison, Healthy Waterways, Healthy Catchments: Making the connection in south east 
Queensland. Moreton Bay and Catchments Partnership, Brisbane Queensland. pp 149-182.

Udy J and Dennison W. C. (2005). Nutrients. In: Abal, E. G., Bunn, S. E. and Dennison, W. C. Healthy Waterways, Healthy Catchments: Making the connection in south east Queensland. pp 93118. Moreton Bay and Catchments Partnership, Brisbane Queensland.

Udy J. W., Fellows C. S., Bartkow M., Bunn S. E., Clapcott J. E., and Harch B. D. (2006). Measures of nutrient processes as indicators of stream ecosystem health. Hydrobiologia, 572, 89-102.

Vertessey R. and McAlister T. (2005). Integration. In: Abal, E. G., Bunn, S. E. and Dennison, W. C. Healthy Waterways, Healthy Catchments: Making the connection in south east Queensland. Moreton Bay and Catchments Partnership, Brisbane Queensland. pp 184-208. 